\title{
Transformational Teaching: Prophet Muhammad (peace be upon him) as a Teacher and Murabbī
}

\author{
Zainab Alwani ${ }^{1}$ \\ Howard University
}

\begin{abstract}
This article analyzes the transformative role of Prophet Muhammad as a murabbi. I apply the hermeneutic of reading the divine text as a structural unity, a concept known as al-wahda al-binā'iyya li-l-Qur'ān. After defining the concept of murabbī, I suggest that a holistic reading of the Qur'an can help us rebuild our concepts from within the Qur'an, a methodological approach that we can use to reshape the current religious discourse. I present the Prophet's (pbuh) mission as a roadmap, a model that envisions a holistic relationship between the Qur'an and the Sunna as its final goal. I then devote special attention to this model by focusing on his teaching strategies and how they impacted the first generation of Muslims. I argue that a strong methodology based on the Qur'an and Sunna can help revive the role of a compassionate Muslim community. I close by stressing the significance of developing this traditional role and applying it in all aspects of contemporary life.
\end{abstract}

\section{Introduction}

Over the span of only twenty-three years, Prophet Muhammad (peace be upon him), following God's revelation, transformed the life of countless individuals and gradually led them to develop the best community in human history. The majority of those who accepted the message were among the weak and the poor, the enslaved and the marginalized. But in a very short period, and within the midst of great hostility and resistance among the elites, they changed themselves into role models for humanity by embodying a higher standard of morality,

${ }^{1}$ Zainab Alwani is the founding director and an associate professor of Islamic studies at Howard University's School of Divinity (HUSD). She is an Islamic scholar, researcher, and community activist. The first female jurist to serve on the board of the Fiqh Council of North America, Dr. Alwani currently serves as its vice-chair. Her research focuses on Qur'anic studies, Islamic jurisprudence, the relationship between civil and religious law in the area of family and gender, and inter-religious relations. She has authored and co-authored a wide variety of publications in both Arabic and English, ranging from textbooks and book chapters to scholarly articles. 
standing for justice, advocating for freedom, honoring humanity, and calling for equity for all. What were the distinct characteristics of Prophet Muhammad that helped induce this social, cultural, and paradigmatic change?

In this paper, I argue that his role as a murabbi - a broad term that encompasses the activities of teaching, mentoring, advising, and guiding - was central to his prophetic mission and ultimate success in spawning a social revolution. I briefly discuss his transformative role in this regard by applying a holistic reading of the Qur'an. More specifically, I apply the hermeneutic of reading the divine text as a structural unity, a concept termed al-wahda albinā'iyya li-l-Qur'ān. ${ }^{2}$ My goal is to present the Qur'anic-Prophetic model of murabbī by using the Prophet's mission as a roadmap (Q. 2:129; 3:164; 62:2).

The term murabbī has many derivatives in the Qur'an. This inspired me to investigate deeper into its meaning in order to understand the role of such a person. I apply the holistic method al-wahda al-bina 'iyya li-l-Qur'ān by reading different applications of this term therein. This method conceives the Qur'an's unity through its linguistic, structural, and conceptual elements, such that the divine text, in its entirety, represents an integrated whole. This approach helped me observe this term's movement and how its meaning changes according to the context in which it is used without violating its original meaning. I discovered that the once-simple meaning in the traditional Arabic language was transformed into a comprehensive divine language, perfectly articulated with eloquence and depth. It is amazing how reading the word conceptually for the explicit purpose of tracing the derivation of words led me to construct the framework of murabbi starting with the Creator as the First and Ultimate murabbi who sent messengers and revelation to ensure that humanity would be guided by a fellow human being (e.g., 21:7). God sent Prophet Muhammad (pbuh) as the role model for humanity (e.g., 33:21 and 7:158) and introduced His last Prophet by proclaiming: "And We have not sent you, [O Muhammad], except as a mercy to the worlds" (21:107). The ultimate goal of his mission was to build the well-balanced Muslim personality, one that draws on its thinking, methods, and behavior to enhance harmonious relationships with our Creator, fellow humans, and surroundings. The institution of brotherhood and sisterhood ( $\mathrm{ta}^{\prime} \bar{a} \mathrm{khi}$ ) was one of the Prophetic strategies for healing and rebuilding the new community.

Prophet Muhammad (pbuh) is the murabbi who was guided by the Divine, the ultimate murabbi $\bar{l}$, and God's expectation that humanity would follow his guidance. Many lessons can be derived from this timeless message, including how to leverage this Qur'anic-Prophetic model. This message, the final divine communication from the Creator, is not restricted to its original audience,

\footnotetext{
${ }^{2}$ For more details of the classical and contemporary debates concerning the method's genealogy, see my article "Al-wahda al-binā'iyya li-l-Qur'ān: A Methodology for Understanding the Qur'an in the Modern Day," Journal of Islamic Faith and Practice, 1:1 (2018): 7-27.
} 
because, being eternal, it is also immutable, regardless of how much the umma regresses, as is the case today. The concept of murabbi reflects the ability of people in any position or role to help each other advance to a higher level of morality. Through the strength of their vision and personality, they are able to inspire one another to change their expectations, perceptions, and motivations so that they can work toward common goals.

All of this raises certain questions: Who is a murabbli? What are this person's characteristics? How did Prophet Muhammad (pbuh) strengthen the relationships between his community's members at all levels? How can we be an instrument of unity as an individual rather than an instrument of division? What are the best practices when it comes to creating healthy relationships, and how can we maintain them? What are the best practices in this model that will help us restore trust among people and embody compassion and mercy at all levels?

After defining this concept, I suggest that applying the methodology of reading the Qur'an holistically is one tool that we can use to rebuild our concepts from within the Qur'an, an approach that will help reshape the current religious discourse. Presenting the Prophet's (pbuh) mission as a roadmap is a model for how it envisions a holistic relationship between the Qur'an and the Sunna. I then devote special attention to his model by focusing on his teaching strategies and their impact on forming the first generation. I suggest that a strong methodology based on the Qur'an and Sunna can help revive the role of a compassionate Muslim community. I close by stressing the contemporary significance of developing this traditional role and applying it to today in all aspects of life.

\section{Literal Meaning: Aim and Scope}

The root of murabbi stems from the same root for $r a b b$ and its related derivations. For example, God refers to Himself as Rabb: the Creator, the Sustainer, and the Cherisher. This term's meaning is so vast that other languages lack an equivalent word for it. Literally, it means to take care of, nourish, sustain, provide for, and raise or bring up. One of its derivatives is tarbiyya. According to al-Raghib alIsfahani (d. 502/1108), the foundational meaning of rabb is tarbiyya," which means to raise and nourish at every stage until the goal is attained." 3 As the Qur'an attests to the definition of its words and determines their specific meaning(s), it is essential to define any term or concept in the light of its unity

\footnotetext{
3 Al-Raghib al-Isfahani was an eleventh-century Muslim scholar of Qur'anic exegesis and the Arabic language. I wrote about his methodology in my article "Al-wahda al-binā'iyya li-l-Qur'ān: A Methodology for Understanding the Qur'an in the Modern Day," Journal of Islamic Faith and Practice 1, no. 1 (2018): 9-10. See al-Raghib al-Isfahani, Al-Mufradāt fì Gharīb al-Qur'ān, ed. Muhammad Seyd Kaylani (Beirut: Dar al Ma'rifa, n.d.).
} 
and divine language, as well as to read it conceptually in order to trace the derivation of its words.

\section{God as al-Murabbī, the One Who Ensures Everything's Growth and Maturity}

The root of rabb and its broad meanings of "caring" and "loving" appear in the Qur'an numerous times. However, the surrounding context reveals that this term is most often referring to God, the Creator. As the Most Merciful and the Ultimate murabbi $\bar{\imath}$, He presents a detailed description of Himself so that there is no confusion or doubt in people's minds as to who and what He is. Although this subject is beyond the scope of this paper, it is important to briefly highlight the major themes that will help us understand and then apply its meaning.

In several Qur'anic passages, God uses "رب العالمين": the Creator, Sustainer, and Cherisher of the Worlds. In the first sūra, God introduces Himself with the verse: "All praise and gratitude is due to Allah, Rabb/the Sustainer of all the Worlds." To remove any possible misunderstanding, He sent prophets and messengers to explain this concept further. In the first conversation between Pharaoh and Moses, God said: "And go, both of you [Moses and Aaron], to Pharaoh and say: "We have been sent by the Sustainer of the Worlds" [26:16]. "Pharaoh asked: "And what is the Sustainer of the Worlds?"” [26:23]. "[Moses] answered: '[He is] the Lord of the heavens and the earth and all that is between them': if you would but [allow yourselves to] be convinced!" [26:24].

This ayah clearly states that God takes care of, nourishes, and fosters everything that exists through every stage of its existence. Hundreds of verses describe God's blessings and illustrate His care. God confirmed that $\mathrm{He}$ distributes our means of livelihood and takes care of all His creations, so we do not need to worry about such things.

And there is no living creature on earth but depends for its sustenance on God, and He knows its time-limit [on earth] and its resting-place [after death]. All this is recorded in a clear book. Enthroned above the waters, it was He who created the heavens and the earth in six days [periods]. [God reminds you of your dependence on Him] in order to test you [and thus to make manifest] which of you is best in conduct. (11:6-7)

In God's capacity as the Owner - rabb also means ownership - God entrusted humanity with being His agents and trustees on Earth. The Qur'an maintains the meaning of $r a b b$ as a caring and loving relationship. For example, the presence of a possessive pronoun, such as "my" Sustainer or "your" Sustainer, mostly reflects a close and intimate relationship between you and your Creator, as in the salät (prayer). Muslims glorify God by bowing down and prostrating saying "subhāna 
rabbiy al- 'adhìm" and, in each sujūd, "subhāna rabbiy al-a 'lā" (87:1 and 56:74 and 96). In the Qur'an, rabb illustrates the movement of a word that not only provokes thought and ideation, but also inspires emotion in the reader or listener.

Every language is influenced by a culture and therefore reflects its needs. In some cultures, $r a b b$ refers to a person who can exert power and control, like a slave-owner. This understanding may lead to a misconception. For example, some dictionaries define "rabb al-dār" or "rabbat al-bayt" as the master/lord of the house or the lady of the house, respectively. ${ }^{4}$ Such definitions emphasize ownership from a materialistic view, rather than the person who takes care of, nurtures, and manages the family's affairs. Therefore, it is essential to use the Qur'anic language as the final arbitrator and the ultimate reference when defining any of its words' meaning(s). This will reframe our understanding and help reduce misconceptions while helping build a positive and constructive understanding of all critical concepts. By defining " $r a b b$ al-dār" in the latter, as opposed to the former, sense, the familial structure is transformed from a hierarchal model into a compassionate one (e.g., 2:187, 3:195, 4:1, 9:71-72, 17:23-34, 30:20-21, and 31:14-16).

As we follow rabb's movement between the Qur'anic meaning and the cultural explanation, there could be a misunderstanding over what it means to be a slave or servant of God versus being enslaved by another human being. The Qur'an refutes this analogy and clearly explains the difference in the following parable.

God makes a comparison between [two men:] a man enslaved [and therefore] unable to do anything on his own accord, and a [free] man upon whom We have given plentiful provision, who gives out from it privately and openly. Are they equal? Praise be to God [alone]! But most people do not know it. God makes another comparison between two men: one of whom is dumb, cannot do a thing, and is a burden on his master. Wherever he sends him on an errand, he brings [him] no good. Is he equal to someone who commands justice and follows a straight path? (16:75-76)

Reading the Qur'an holistically shows us that the divine text defines its concepts so precisely that no space is left for any misunderstanding or misconception. God clearly explains the difference between His and the people's measurements, especially when there is a tendency to confuse the two: "Indeed, We have offered in this Qur'an every evidence and lesson by way of parables and examples for people so that they may think and take heed" (39:27) and "So God propounds

\footnotetext{
${ }^{4}$ Hans Wehr, A Dictionary of Modern Written Arabic, ed. J. Milton Cowan (Ithaca, NY: Spoken Language Services, 1976), 320-21.
} 
parables for human beings, that they may reflect on them and infer the necessary lessons" (14:25). Parables help people understand abstract concepts by alluding to shared experiences and allowing readers to feel as if they are direct observers of these experiences. By using carefully selected or crafted parables, remote and abstract truths can be made more comprehensible. For example, whenever there is a chance that people might confuse or corrupt a concept, the Qur'an uses parables. Qur'an 16:75-76 is a good example of this.

The divine text presents parables in a variety of forms ${ }^{5}$ to convey intellectual, spiritual, and moral knowledge and also employs symbolic language to express things that we cannot always put into words. This technique enables people to visualize and gain at least a basic understanding of the knowledge and concepts being conveyed. Given that the subject is associated with something that we already know and thus can be understood within a familiar context, we can better learn and retain that information. Moreover, there is a greater chance that we will reflect upon it.

The purpose of a parable is not to state the obvious, but to illuminate subtle differences or unexpected similarities between two subjects. This is how the Qur'an removes any pre-existing concepts or understandings that may cause confusion between the two issues. Therefore, being a true servant of the Creator is the noblest rank and represents the ultimate freedom that one should seek to achieve, whereas being enslaved to anyone or anything strips the person of his/her free will, namely, the covenant between God and humanity.

God wants us to worship Him by our own free will trust (amāna): "We did indeed offer the trust to the heavens, the earth and the mountains, but they refused to bear it, and were afraid of it. Yet humanity accepted it" (33:72). Once humanity accepted this responsibility, God entrusted us with acting as His trustee/steward on earth: "Remember when your Sustainer said to the angels, 'I am putting a trustee (khalifa) on earth'?" (2:30). With this, the Creator, the One Who owns all knowledge and wisdom, entrusted humanity with maintaining this world's balance, peace, tranquility, fairness, justice, and sustainability. And, of course, humanity will be held accountable for how it carried out this trust. Therefore, being servants or slaves of God is in no way equal to any type of human servitude or enslavement.

God asserts His love and care for humanity: "And [tell them that] I have not created the jinn and humanity to any end other than that they may [know and] worship Me. [Besides] no sustenance do I ever demand of them, nor do I demand that they feed Me, for verily God Himself is the Provider of all sustenance, the mighty One, the Eternal" (51:56-58). In this context, God wants people to

${ }^{5}$ See Mohammed Jaber al-Fayadh, al-Amthāl fì al-Qur'ān al-Karìm / The Proverbs of the Glorious Qur'an, 2nd ed. (Herndon, VA: International Institute of Islamic Thought, 1995). This Arabic-language book can be found online at https://books-library.online/a-2494-download. 
worship and devote all acts of worship to Him Alone by their own free will. The Qur'an gives the example of Ibrahim, who announced his submission to God in a beautiful supplication.

Now [I know that,] verily these [false deities] are my enemies [and that none is my helper] except the Sustainer of all the Worlds, who has created me and is the One who guides me. It is He who feeds me and gives me drink. When I am ill, it is He who cures me and who will cause me to die and then will bring me back to life - and who [I hope,] will forgive me my faults on Judgment Day! O my Sustainer, endow me with the ability to judge [between right and wrong] and make me one with the righteous. $(26: 77-83)$

This passage both articulates the meaning and role of a murabbi and presents God, the Most Merciful and Most Gracious, as the best murabbī. Not only does it convey the idea of fostering, bringing up, or nourishing, but also the concepts of guiding, monitoring, accomplishing, cherishing, sustaining, and bringing to maturity, via a process of spiritual evolution, from the earliest state to that of the highest perfection. To implement this method correctly, from time to time God the Most Merciful sent prophets and messengers to ensure that humanity would be guided by one of their own who would serve as their role model.

Indeed, We sent aforetime Our messengers with all evidence of [this] truth. And through them We bestowed revelation with clear signs and sent down with them the Book and the Balance (of Right and Wrong) so that people might behave with equity and stand forth in justice. $(57: 25)$

\section{Prophet Muhammad (pbuh) as a Murabbī}

God sent Prophet Muhammad (pbuh) as a role model for humanity (e.g., 33:21 and 34:28):

Say [O Muhammad]: "O humanity, verily, I am the Messenger of God to all of you, [sent by Him] unto whom the dominion over the heavens and the earth belongs. There is no deity except Him; He [alone] gives life and causes death." Believe, then, in God and His Messenger - the unlettered Prophet, who believes in God and His words - and follow him so that you may be guided. $(7: 158)$

This explains that Prophet Muhammad (pbuh) is the murabbi guided by the Divine, the ultimate murabbi , and that God expects humanity to follow His 
guidance. Thus, the Prophet's (pbuh) actions and characteristics embodied the Qur'an. To further solidify this point, when his wife A'isha was asked about his character, she replied, "Do you not read the Qur'an? His character was embodied in the Qur'an." If she had been asked how he had worshipped, parented, conducted his marital affairs and business transactions, and so on, she would have replied the same way: "His Prophet's (pbuh) core mission. ${ }^{6}$ was embodied in the Qur'an." This was the

The Prophet was entrusted with a heavy responsibility - building a community firmly grounded in the Qur'an's teachings - as articulated in one of the first revelations: "Soon shall We send down to you a weighty message (73:5)." How could he fulfill this responsibility other than by serving as its living embodiment? Every breath he took, every decision he made, and every word he spoke had to be completely aligned with God's message. For example, how did he teach people that being servants or slaves of God had nothing in common with their current understanding of servitude and slavery?

With the guidance of the Qur'an, Prophet Muhammad (pbuh) wisely and gradually introduced changes to the established culture by presenting its concepts in a way designed to root out the existing misconceptions.

First: He began to deconstruct this particular misconception by emphasizing the concept of tawhìd (Islamic monotheism) and explaining God's attribute of Rabb, the Most Merciful. He emphasized the meaning of submitting oneself to God/the Creator alone and employed appropriate pedagogical strategies for teaching everyone on his or her level to make sure that they understood him clearly. Ibn Abbas reported

One day I was behind the Prophet (peace and blessings of Allah be upon him) [riding on the same mount] and he said, "O young man, I shall teach you some words [of advice]: Be mindful of Allah, and Allah will protect you. Be mindful of Allah, and you will find Him beside you. If you ask, then ask Allah [alone]; and if you seek help, then seek help from Allah [alone]. Know that if all of humanity gathered together to benefit you with anything, they would not benefit you except with what Allah had already prescribed for you. Likewise, if all of humanity gathered together to harm you with anything, they would not harm you except with what Allah had

\footnotetext{
${ }^{6}$ It is mentioned in the lengthy story that Sa'd ibn Hisham ibn 'Aamir asked 'A'isha about some matters while he was Madina. He said: "I said: O Mother of the Believers, tell me about the character of the Messenger of Allah (S)." She replied: "Do you not read the Qur'an?" I said: "Of course." She stated: "The character of the Prophet was the Qur'an." I wanted to get up and not ask about anything else until I died..." Narrated by Muslim, 746.
} 
already prescribed against you (35:2). The pens have been lifted, and the pages have dried." 7

Second: To remove any misunderstandings and misconceptions, the Prophet (pbuh) taught that the human family is one and that all people are created equal in terms of worth and value, regardless of race, ethnicity, gender, or class. All of our ancestral lineages extend back to Adam and Eve, for all human beings are sisters and brothers. Therefore, instead of disdaining, betraying, or humiliating anyone, we should strive to guide them, light their path, and walk with them along the path to heaven. This replacing of old concepts with new ones is clear in the following hadith: Abu Hurayra reported Allah's Messenger (新) as saying: "None of you should say 'my slave and my slave-girl,' for all of you are the slaves of Allah, and all your women are the slave-girls of Allah. Rather, call them 'my young man' and 'my young girl.",8

Third: To confirm this new compassionate relationship, Prophet Muhammad (pbuh) highlighted the meaning of brotherhood and sisterhood: "Allah has made some of your brothers as servants under your care. So whoever has his brother under his care, then let him feed him from his food, and let him clothe him from his clothes. Do not give him a duty that he cannot bear. And if you [nevertheless] give him a duty that he cannot bear, then assist him with it."9

This means that the murabbi of the Prophet (pbuh) was the divine guidance and light of the Qur'an. His most distinctive quality, however, was the fact that he was a blessing to everyone in both word and deed. He infused justice, mercy, love, and dignity in all of those around him, spread the meaning of brotherhood/sisterhood to such an extent that it became an exceptional experience in human history. Thus, given all of the above, being a true servant of the Creator is the noblest rank that one should seek to achieve. The Qur'an describes Prophet Muhammad (pbuh) as His 'abd: "And if you doubt any part of what We have revealed step by step upon Our 'abd (slave or servant [Muhammad]), then produce a süra of similar merit and call upon any other than God to bear witness for you, if what you say is true" (2:23).

Indeed, being true servants is not restricted to the prophets, for God describes in a beautiful way His true 'ibād (sing. ' $a b d$ ) among the believers: "For [the true] servants of the Most Merciful are [only] they who walk gently on earth, and who, whenever the ignorant address them, reply with [words of] peace" (25:63). Therefore, when Muslims stand before God in prayer and recite the first süra,

\footnotetext{
${ }^{7}$ Sunan al-Tirmidhī, 2516. He graded it as sahīh (authentic).

${ }^{8}$ Șah̄ịh al-Bukhārī, 2434; Saḥ̄h Muslim, 4275.

${ }^{9}$ Hadith of Jāmi ‘ al-Tirmidhī , 1945, Grade: sound hadith.
} 
they declare complete submission to their Creator by repeatedly reciting "You alone do we worship, and to You alone do we turn for help" (1:5-6).

God servants are to actively reflect upon and observe His creation (e.g., $3: 19,2: 219,13: 3$, and 30:21). This critical thinking is what the first revelation called for, for "Read" combines the two readings: that of the revelation and that of reading (and reflecting upon) God's creation: "There are signs in details for those who reflect" (10:24). After ensuring that one gets one's facts straight, one is expected to draw the correct conclusion(s).

Indeed, in the creation of the heavens and the earth and the alternation of the night and the day are signs for those of understanding, [and] who remember God when they stand and when they sit, and when they lie down to sleep. And [so] reflect on the creation of the heavens and the earth, saying: "O our Sustainer, You have not created all this without meaning and purpose. Glory be to you! Keep us safe, then, from the torment of the Fire." (3:190-91)

God continued inviting humanity to reflect and make sure that its members would submit and worship Him alone with their free will: "Such is the Creation of Allah. Now show Me what is there that others besides Him have created..." (31:11).

The Qur'anic-Prophetic understanding of murabbi is purposeful and builds commitment toward positive changes that are inclusive of people and their diverse viewpoints, empowers those involved, is ethical, and recognizes that all of these elements are accomplished by relational and ethical processes. The Prophet's (pbuh) mission outlines the main strategies of a murabbi: "Indeed, God bestowed a favor upon the believers in sending a Messenger from among themselves to recite His verses unto them, mentor their growth in purity, and teach them the Book and wisdom, whereas before that they were, indeed, most obviously lost in error"'(3:164).

His mission shows us how to implement the Qur'an in our life practically and develop thereby a compassionate community. The Qur'an clearly defines this mission and therefore is considered a significant methodology in terms of presenting both a theoretical and a practical transformative model of murabbi Using this defined mission helps us (1) understand the significance of the Qur'anSunna relationship, (2) how Prophet Muhammad (pbuh) followed the Divine instruction and teachings, (3) his main strategies for implementing them in real life, and (4) how the Qur'an assessed and guided him during the process of implementation.

As history shows, these goals were achieved via a several long-term process in which some of the Companions played a leading role. 
- Tilāwa: Spreading knowledge and providing everyone with access to the Divine knowledge by reciting, conveying, and following the revealed Book of God to acquire purity (tazkiya).

- Tazkiya: Mentoring the process of people's growth holistically, namely, spiritually, intellectually, and socially.

- Teaching: Demonstrating the Qur'an's implementation in order to gain hikma (wisdom) (e.g., 2:151, 3:164, and 62:2).

Therefore, the body of knowledge known as "the Sunna" presents a model for applying the Qur' an to real-life situations and remains a practical experience of living a human life at the highest possible level, as practiced by the Prophet (pbuh). His words and actions must not be examined piecemeal, but in their entirety as an overall phenomenon ordered by universal laws and principles that can be studied and analyzed. In other words, the Sunna can only be understood correctly when it is placed within a larger framework, namely, the Qur'an.

\section{The Derivatives of Ribbiyyūn and Rabbāniyyūn}

Reading the Qur'an holistically allows us to reflect deeply upon the meaning of its words, like $r a b b$, and uncover the vastness of divine guidance. This is how the Qur'an is able to interact with every person on a very personal level while maintaining its integrity as the absolute book of guidance for the masses. As it continues to construct and broaden the landscape of murabbi $\bar{\imath}$ as a communal attribute that facilitates compassion, it introduces the concepts of ribbiyyūn and rabbāniyyūn, which are derived from $r a b b$. Rabbāni is used in four verses, three of which include rabbāniyyūn (i.e., 3:79, 5:44, and 5:63) and once using ribbiyyūn (3:146-48). Ribbiyyūn came in the context of commending the first generation of believers and supporters of the prophets as role models for later generations (3:146-48). The Qur'an presents rabbāniyyūn for those people of knowledge (i.e., scholars) who are devoted to building a close connection with their Creator, practicing what they learn, and spreading His message. After providing a clear description of their characteristics and roles, the Qur'an then analyzes how their actions impact their communities.

These scholars' first step is to hold themselves accountable for reading and interpreting the Book of God in a way that reflects His message and to adhere to its true meaning (3:79-80). The second step is to define this message clearly so people understand what they are accountable for achieving. In this case, the scholars are responsible for developing effective strategies and establishing best practices for learning and teaching God's message, and then for generating the correct tools to assess and evaluate that knowledge and its practical impact upon 
people's lives. God-devoted people, by virtue of their submission to tawhīd, are committed to a lifetime of doing what is good and forbidding what is evil in order to fulfil the purpose of life: serving as God's trustees. This process includes observing and mentoring people while they gain knowledge, similar to how the Qur'an corrected behaviors, customs, and unjust practices in real-time. Eventually, this knowledge will be transformed into reality and change people's lives by inculcating the divine teachings into their interests and behavioral orientations as individuals, groups, and cultures.

At the same time, these scholars must evaluate the practices, cultures, and traditions that were established based on what they taught $(5: 62-63)$. Once people understand the message clearly and observe their proper role models, the moral community will be established. It is important to remember that doing good and forbidding evil is not the role just of the individual, but also of the community: "And that there might grow out of you a community [of people] who invite unto all that is good, and enjoin the doing of what is right and forbid the doing of what is wrong: and it is they, they who shall attain to a happy state" (3:104). The ulama's most crucial role is to understand a revelation's meaning and then articulate the relevant methodology that would make Islamic principles relevant to any society, one that would fulfill the Islamic obligation to expend one's utmost effort to serve the Creator.

\section{Mothers and Fathers as Murabbī}

The final cornerstone of this Qur'anic framework concerns parenting. The Qur'an provides several relevant examples to reflect this significant aspect, among them examples of some of the prophets and their relationship with their children, one of which concerns an example of an ordinary man who fulfilled his role as a parent effectively. All such narratives are used to inform people that there is no excuse for being a poor murabbi, as pointed out by Luqman's conversation with his son in Süra Luqmān.

The verb rabba is mentioned in two places: First, in the context of the child-parent relationship when the parents get older: "And, out of kindness, lower to them the wing of humility, (treat them with humility and tenderness) and say, "O my Lord. Have your Mercy/Compassion on them, as they brought me up (when I was) little" (17:24). Indeed, the Qur'an used the same word (rabba) in the second context - that of the parent-child relationship in the case of foster parenting - as Pharaoh reminded Moses: "[But when Moses had delivered his message, Pharaoh] asked: 'Did we not bring you up among us when you were a child? And you remained among us for (many) years of your life?"' (26:18).

In the similar context, the Qur'an uses rabā'ibukum (sing. rabibah) for the step-daughter or step-son from previous marriages, meaning "those whom you 
have raised." By doing so, it emphasizes murabbl$\vec{\imath}$ meaning of the moral responsibility of raising a child, therefore forbidding a step-parent from marrying a step-child. This protects the children from certain types of abuse and enables them to be treated as their step-parent's own children.

Prohibited to you (for marriage) are your mothers, daughters, and sisters; father's sisters and mother's sisters; brother's daughters and sister's daughters, foster-mothers (who gave you suck), foster-sisters, and your wives' mothers; your step-daughters under your guardianship, born of your wives with whom you have consummated your marriage. (4:23)

In conclusion, the Qur'an portrays the trustee (murabbi) as an active and Godconscious person who is always mindful of His presence and self-aware. Those who maintain good relations with everybody, respect the surrounding social and physical environment, and see nature as God's signs are responsible for preserving, cultivating, and enhancing the condition of their surroundings (e.g., trees, rivers, and mountains). They envision themselves in this world as travelers moving toward their final destination: the hereafter. Therefore, they spend their time working to disseminate good and eliminate evil as well as making proper judgments on all aspects of life. Fulfilling these aspirations obliges them to develop their rational and spiritual faculties; activate their mind, heart, and body; observe and monitor their feelings and desires constantly; assume full responsibility for their actions and correcting their mistakes; and change their behavior and lifestyle when necessary. In other words, they are humble and good recipients of advice given by the Qur'an and Sunna, as well as other people.

\section{Modeling and Teaching Compassion and Mercy}

\section{The Contemporary Relevance of This Prophetic Model}

Along with all other communities, Muslims are also facing many challenges due to the sweeping changes, both internal and external, being witnessed in the world. While external challenges come from our surroundings, internal ones occur within their community. The first and foremost internal challenge Muslims need to overcome is disunity. As we know, the Prophet's (pbuh) mission was to bring peace and unity to Arabia's feuding pre-Islamic tribes. Disputes over who would should lead the umma after his death eventually led to the most serious - and ongoing - intra-Muslim schism. Such communal disunity reflects more than just its people's internal differences and disagreements over ideas and practices, for history shows that such a reality can easily turn into a chronic disease that negatively affects every part of the community. That is why the Prophet (pbuh) 
beautifully described how the umma should be united: "The parable of the believers in their affection, mercy, and compassion for each other is that of a body. When any limb aches, the whole body reacts with sleeplessness and fever." 10 With this in mind, how can we really preserve the umma's unity? How can we be an instrument of unity as an individual, rather than an instrument of division?

Again, the Prophet (pbuh) showed the Companions how to use the Qur'anic-Prophetic model of murabbī to heal and rebuild compassionate communities through his words and actions, all of which embodied and cultivated compassion and mercy (21:107). This means that while outlining the framework, Muslims must take compassion and mercy into consideration before taking any step. In his role as a murabbī, the Prophet (pbuh) outlined the main strategies of this transformational mission in a way designed to inspire his followers to both achieve extraordinary outcomes and, in the process, help his followers grow and develop into compassionate and caring individuals.

And how did he accomplish this? By responding to each individual's needs by empowering all of them and aligning all of their objectives and goals, be they a follower, the leader, or the larger community. And how was this accomplished? By building the compassionate community, a process that began with reciting the Qur'an:

God commanded his Prophet to recite, convey, and follow the Qur'an. Whoever follows its guidance, follows it only for the good of his own soul. As for him who goes astray, just say, "I am only a warner." Then say, "Praise be to God! He will show you His signs and you will recognize them. Your Sustainer is not unaware of what you do." (27:92-93)

\section{The Qur'anic-Prophetic Model of Murabbī: The Prophet's (pbuh) Mission}

The Prophet (pbuh) began the process of building a moral and compassionate community by actively immersing himself in the lives of people from all backgrounds (one human family), for God instructed him to surround himself with those who accepted the message:

And recite/convey [to the world] whatever has been revealed to you of your Sustainer's Book. There is nothing that could alter His words, and You shall find no refuge other than with Him. Keep yourself patient [by being] with those who call upon their Sustainer in the morning and the evening, seeking His countenance. Let not your eyes pass beyond them,

\footnotetext{
${ }^{10} \mathrm{Al}-\mathrm{Nu}$ 'man ibn Bashir reported: "The Messenger of Allah, peace and blessings be upon him..." Source: Sahịh al-Bukhārī 6011, Book 78, Number 42 and Vol. 8, Book 73, Number 40; Sahịh Muslim, Book 32, Number 6258.
} 
desiring the adornments of the worldly life. Do not obey one whose heart We have made heedless of Our remembrance, because he had always followed [only] his own desires, abandoning all that is good and true. $(18: 27-28)$

During his time in Makka, Prophet Muhammad (pbuh) focused on teaching and applying the Qur'anic vision of tawhìd and infused justice, mercy, love, and dignity into all of those around him. He spread the power of brotherhood/sisterhood to such extent that it became an exceptional experience in human history.

\section{Compassion and Mercy: Divine Attributes}

He was guided by the Creator to bring healing and build a compassionate umma:

And it was by God's mercy that you [O Prophet] did deal gently with your followers, for if you had been harsh [in speech] and hard-hearted, they would indeed have broken away from you. Pardon them and pray that they be forgiven. Take counsel with them in all matters of public concern [and] then, when you have decided upon a course of action, place your trust in God, for, verily, God loves those who place their trust in Him. (3:159)

The Prophet (pbuh) was attentive to the role that emotion plays in shaping a compassionate community. This requires a systematic understanding not only of the feelings associated with firsthand experiences of trauma, but also of how these affective reactions can spread and generate collective emotions, thus producing new forms of animosity. Addressing this challenge in the ways that he did showed his awareness of how a conscious and active appreciation of the whole spectrum of emotions - not only of anger and fear, for instance, but also of empathy, compassion, and love - may facilitate more lasting, organic, and honest forms of social healing and reconciliation. ${ }^{11}$

The Prophet (pbuh) acknowledged the roles of forgiveness and reconciliation in social reconstruction. Forgiveness promotes both trustworthy and trusting behavior, which can lead to reconciliation, both of which, when joined together, help heal past memories, restore trust, and thus pave the way for preventing future cycles of trauma. Forgiveness can lead not only to inner peace within an individual, but also to building peace within a community torn apart by conflict and trauma.

\footnotetext{
${ }^{11}$ Anas ibn Malik reported: The Messenger of God, peace be upon him, said, "Do not despise each other, do not envy each other, do not turn away from each other, but rather be servants of God as brothers and sisters. It is not lawful for a Muslim to boycott his brother for more than three days." Source: Sahịhh al-Bukhārī, 5718, Șahīh Muslim, 2559. Muttafaqun 'alayhi (authenticity agreed upon), according to al-Bukhārī and Muslim.
} 
In addition, he offered a conceptual engagement with processes of holistic healing and reconciliation, thereby showing that emotions are central to how communities experience and work through the legacy of catastrophe. The Prophet (pbuh) proposed a comprehensive and profound plan to bring the community together through a process comprising three concepts and goals: ta 'àruf (getting to know one another genuinely), ta' $a \bar{l} l u f$ (building harmonious relationships within the community), and $t a$ ' $\bar{a} w u n$ (collaborating with one another).

One of the interesting steps he took to transform the hostile environment into a compassionate and balanced community (umma wasta) was to change Yathrib's (rebuke) name to al-Madina al-Nabī (the city of the Prophet) or alMadina al-Munawwara (the enlightened [or radiant] city). Today, this innovative marketing strategy is called "repositioning" or "rebranding." He enforced a rule that anyone who said "Yathrib" once should seek God's forgiveness ${ }^{12}$ in order to inculcate this cultural shift into the people's hearts and minds. As Makka's Muslim migrants settled into their new homes as refugees, Madina's Muslim inhabitants welcomed them with love and compassion and voluntarily shared their land (59:8-9).

In order to build the system of ta 'àruf, the Prophet (pbuh) then developed a revolutionary social system based upon brotherhood and sisterhood, whereby the indigenous Muslim inhabitants (Anșār [allies]) opened their homes and businesses to the refugees (Muhäjrin). This infusion of a culture of unity dispelled any sense of superiority between the two groups, promoted equality and equity, and led to ta' $\bar{a} l u f$. Moreover, he focused on building a community that prioritized other's needs over one's own, on expelling the diseases of the heart (e.g., greed, selfishness, envy, and hate) and replacing them with love, compassion, and mercy. This foundation of brotherhood/sisterhood was based on mutual economic and psychological support and the principle of being inheritors to each other, which, in turn, sought to provide the homesick migrants with enough support to overcome their sorrow and misery.

This brotherhood/sisterhood arrangement brought prosperity, solidarity, tolerance, and peace to the community. In this regard, the Prophet's (pbuh) goal was to establish that loving and compassionate relations organically not by choosing two random Muslims to become brothers or sisters, but by investigating his followers carefully and then proclaiming their new relationship. For instance, there was

\footnotetext{
${ }^{12}$ Ahmad narrated from al-Bara' ibn Azab that he had removed it from Yathrib, so let it be forgiven by Allah. Țābah is Țābah. "Whoever calls Madina Yathrib, it is necessary for him to repent. Madina is Țābah, Madina is Țābah." [Narrated by Bara' ibn 'Azin, Musnad Imām Aḥmad ibn Hanbal, 4:285]. Tâbah means "the good one" or tayyibah (the pure), while Yathrib means "to rebuke, reprimand, and blame." See al-Raghib al-Isfahani, Al-Mufradāt fï Gharīb al-Qur'ān, 79.
} 
exact harmony between Salman al-Farisi and Abu Darda' in terms of character, likes, and feelings, and so he made them brothers.

One day, Salman went to see Abu Darda' and found his wife looking disheveled (her appearance was not that of a married woman). He asked her: "What's wrong?" She replied: "Your brother Abu Darda' has no worldly desires." Then Abu Darda' arrived and prepared some food for Salman and said: "Go ahead and eat, I am fasting." Salman said: "I shall not eat unless you eat with me." So Abu Darda' ate with him. At night Abu Darda' arose for the voluntary prayer. Salman told him to go to sleep, so he slept. This happened again. Toward the latter part of the night Salman said to him: "Wake up," and both offered the prayer together. Then Salman said: "It is true that you owe your duty to your Creator, but you also owe a duty to yourself and to your wife. So you should carry out your duty to everyone." Then they went to the Prophet (pbuh) and related all that had transpired to him. He said: "Salman was right." 13

This concept of 'amr bi al-ma'rüf wa nahiy 'an al-munkar (enjoining the right/honorable and forbidding the wrong/dishonorable) seeks to replace oppression at all levels of society with justice $(3: 104,110$, and $114 ; 7: 157 ; 9: 71$ and $112 ; 22: 41 ; 31: 15$ and 17$)$.

Prophet Muhammad (pbuh) shifted the culture from one of material competitiveness to moral competition and encouraged ta'a wun (collaboration with one another). He frequently encouraged people to visit the sick, feed the poor and needy, take care of orphans, and attend funerals. ${ }^{14}$ He developed a system that melded the moral, ethical, and legal constructs into one dynamic structure that became a way of life, as opposed to handing down rigid governing laws of rights and prohibitions. The Prophet (pbuh) promoted a culture of moral and ethical accountability by telling people not to sleep if their neighbors were hungry and not to allow orphans to fend for themselves, among many others things. The newly established tradition of brotherhood/sisterhood prevented several possible conflicts by ending animosity based on tribalism and racism, as well as arrogance based on wealth. Compassion and respect developed among all of the city's Muslims. One can argue that this tradition can be considered among history's

\footnotetext{
${ }^{13}$ Șahīh al-Bukhārī, Volume 8, Book 73, Number 161.

${ }^{14}$ Abu Hurayra reported: The Messenger of Allah, peace and blessings be upon him, said, "A Muslim has [been] given rights over another Muslim: to return the greeting of peace, to visit him when he is sick, to follow his funeral procession, to answer his invitation, and to respond to his sneeze." In another narration, the Prophet said, "When he seeks your advice, you counsel him." Source: Șaḥị̣ al-Bukhārī, 1183, Șaḥịh Muslim, 2162.
} 
most important and exemplary practices of integrating a society's disparate fragments.

The Qur'an defines this community's characteristics as follows: "You are indeed the best community that has ever been brought forth for [the good of] humanity. You enjoin the doing of what is right and forbid the doing of what is wrong, and you believe in God" (3:110) and "Thus have We made of you an umma justly balanced, that you might be witnesses over the people and the Messenger will be a witness over you" (2:143).

The Qur'an reminds us of God's mercy in building ta'äluf among the believers as long as we do our job as a community:

And remember the blessings that God has bestowed upon you: how, when you were enemies, He brought your hearts together so that through His blessing you became brethren; and [how, when] you were on the brink of a fiery abyss. He saved you from it. In this way God makes clear His messages to you so that you might find guidance. (3:103)

\section{How Did This Model Maintain Peace and Tranquility in a Divided Community?}

One must study how the Prophet (pbuh), as a murabbī, sustained compassionate and peace among all of Madina's inhabitants and especially at a time when the Muslims were surrounded by both internal and external enemies. Unfortunately, such a study is beyond the scope of this article. Rather, I argue that Sürat al-Nūr provides one of the best examples of an incident that almost divided the entire community - Aisha, the Mother of the Believers, being accused of adultery. The community, which was not immune from the Hypocrite 'Abd-Allah ibn Ubayy's insinuations, was in turmoil for over a month until this süra was revealed. During this period, the Hypocrites successfully deceived some sincere believers and even got them to join in the slander. Sürat al-Nür not only defended the Mother of the Believers, but also provided a preventive model for avoiding such a moral disaster in the future.

This experience was an extensive training session that required people to go through an internal and external filtering process under the observation of the Divine. Hypocrites at every stage of Islam's history have played a pivotal role in igniting rumors, controversies, and accusations designed to undermine the community's moral foundations. The Qur'an illustrates and teaches us how to diagnose this social problem by laying out a comprehensive and systematic methodology to deal with false accusations. The principles of carefully evaluating one's words and actions, as well as the mechanisms that should be developed to 
hold people accountable based on their actions, surfaces in more than one context in the Qur'an. ${ }^{15}$

\section{The Qur'anic Strategy against Rumors: An Analytical Reading of Sūrat al- $N \bar{u} r$}

How does the Qur'an describe and analyze this experience? What are the main issues that it emphasizes? How does it examine the people's attitude toward this slander? Does it provide guidance and strategies for dealing with similar problems? According to the Qur'an, what is the problem? Why is it important to analyze people's stands on such issues? How do we define the relationship between the Qur'an and Sunna in light of this sürah?

Clear rules can be formulated from this süra. First, as God says, assess the people who instigate and circulate a story without confirmation and then hold them accountable: "Indeed, those who came with a falsehood among you are a group among you. Do not regard it as a misfortune, for it is good for you. Every one of them shall be held to account for the sin he has committed, and he who took the greater part in it shall have a terrible punishment" (24:11).

Second, establish strong relationships among the community based on trust and compassion: "Why, when you heard it for the first time, did not the believing men and the believing women think good of one another and say, 'This is an obvious falsehood'?" (24:12)

Third, verify the story before making any comments or statements. Those who spread lies must face the consequences: "Why did they not bring four witnesses? And when they do not produce the witnesses, then it is they in the sight of God who are the liars. Had it not been for the favor of God upon you, and His mercy in this world and the hereafter, you would have been touched for that lie in which you were involved by a great punishment" (24:13-14).

Fourth, be mindful of what you say because your words could cause irreparable damage by creating problems that lead to internal conflict: "When you received it with your tongue and said with your mouths that which you had no knowledge of, you thought that it was an insignificant thing, while in the sight of God it was something very great" (24:15-16).

Fifth, create mechanisms to help prevent rumors from spreading: "Why, when you heard it, did you not say: 'It is not for us to talk about this. Glory be to You, this is a great lie. God warns you against doing this forever, if you are true believers. God explains the commandments clearly to you, and $\mathrm{He}$ is the AllKnowing, the All-Wise"” (24:17-18).

\footnotetext{
${ }^{15}$ See my upcoming article: "With 'A 'isha in Mind: Reading Sürat al-Nūr through the Qur'an's Structural Unity" in Dina Elomari and Juliane Hammer, eds. Muslima Theology (Routledge, forthcoming).
} 
Sixth, set firm rules of accountability for those who spread gossip and slander: "Those who love (to see) scandal broadcast among the believers will have a grievous penalty in this life and in the hereafter. God knows, and you know not" (24:19).

Seventh, and lastly, strengthen your relationship with God and seek His guidance: "But for the grace of God and His mercy upon you, and were not God compassionate and merciful, [you would have come to grief]" (24:20).

Some of the mechanisms to help prevent rumors from arising and spreading are mentioned in Sürat al-Hujurät, which was revealed in Madina in 9 AH. This mechanism is designed to regulate and balance human relationships by identifying the predictable consequences. For example, spying, mockery, and backbiting are destructive in nature, whereas being honest, trustworthy, truthful, just, and forgiving strengthen relationships. Each family member has rights and responsibilities that further regulate healthy relationships. Human beings are encouraged to learn how to work together in order to accomplish their goals.

\section{The Prophetic Pedagogy: Tilāwa, Broadcasting Knowledge, and Attaining Tazkiya}

God commanded His Prophet (pbuh) to recite and convey the Qur'anic message. Thus, we are told: "Indeed, God bestowed a favor upon the believers when He raised up in their midst a messenger from among themselves to convey His messages unto them (yatlī 'alayhim āyātihi), to cause them to grow in purity, and to impart unto them the Book as well as wisdom (3:164).

Yatlu is often rendered as "recite" or "rehearse"; however, it has another meaning as well: to follow or imitate. God Almighty says: "Consider the sun and its radiant brightness, and the moon as it reflects the sun" (91:1-2). A more literal translation of "reflects the sun" (wa al-qamar idhā talāhā) would be "as if [the moon] follows it [the sun]." The moon derives its light from the sun, and in this sense is the sun's "follower" or "successor," similar to how we should derive light from the Qur'an and reflect it in our lives. ${ }^{16}$ In 11:17, yatlu might also be understood as conveying the message by reciting the divine text's verses. Hence, the recitation (tilāwa) of God's Book may mean not only to recite and convey the $\bar{a} y \bar{a} t$, but also to follow them and translate their meaning into reality.

[It is] they who read/[truly] follow the Book of Allah are constant in prayer and spend on others, secretly and openly, out of what We provide for them as sustenance. It is they who may look forward to a bargain that can never fail, for He will grant them their just rewards and give them yet

\footnotetext{
${ }^{16}$ Taha Jabir Al-Alwani, Reviving the Balance: The Authority of the Qur'an and the Status of the Sunnah, trans. Nancy Roberts (London and Washington: The International Institute of Islamic Thought, 2017).
} 
more out of His bounty, for verily He is much-forgiving, ever-responsive to gratitude. (35:29-30)

All people without exception are urged to read, contemplate, and gain knowledge through this Divine revelation. "Read," as proclaimed in $96: 1$, is both a command and a comprehensive guide to teach us how to read the Book of God and to engage with His creation combining the two readings in a way that helps us attain purification (tazkiya) and reflect it in every aspect of our life.

How did the Prophet (pbuh) practice this tilāwa, which is considered the cornerstone of his mission? Since the Qur'an is the final revelation from the Creator to humanity, it was revealed to bring all people out of the depths of darkness and into the light. Therefore, it is a source of belief, thought, worldview, and conceptualization. This creative source of holistic knowledge and guidance gives the necessary order to establish human concepts; clarify the relationships between the Creator, humanity, and the universe; and then regulates them in such a way that they will bring about an integrated tawhìd $\bar{l}$-based society.

As a result, reading, reciting, and conveying its a $\bar{y} \bar{a} t$ and message is significant in attaining tazkiya, which transcends personal spirituality and leads to interpersonal growth. Tazkiya is a continuous process of purification that maintains one's spiritual health, removes what is harmful for its growth, and moves it toward the height of purification. The foremost quality of mind and character that flows from this commitment is a state of constant vigilance or an awareness of the presence of God, the All-Knowing taqwä. The root-letters $w-q-y$ mean "to protect," "to save from destruction," and "to preserve." Tazkiya is the important process of building this quality of God-consciousness. Taqwā is at the heart of those traits cultivated by tilāwa and the constant remembrance of God. Its most important and basic function is to allow people to correctly examine themselves and to distinguish right from wrong.

To the extent that, as described by Fazlur Rahman, "one is able to perform this moral self-X-raying"; this muhāsaba, one has "protected" oneself from error and its self-destructive consequences. ${ }^{17}$ Therefore, accountability becomes both a moral as well as a social obligation. The Qur'an describes taqwā as the best "garment" one can wear (7:26) and the "best provision" one can take for the future (2:197). In other words, it is the best guarantee for building a good character. Although taqwā must be rooted in our inner faith, it has to be reflected in our actions (4:135 and 5:8), as stated in "Cooperate with each other on the basis of righteousness and taqwa , not on the basis of sin and transgression" (5:2).

Therefore, the Prophetic mission serves the critical role of embodying the Qur'anic message and values and applying them to guide one through this worldly

${ }^{17}$ Fazlur Rahman, "Some Key Ethical Concepts of the Qur'ān," The Journal of Religious Ethics 11, no. 2 (Fall, 1983):170-85. 
reality. In order for humanity to continue receiving this revealed knowledge from its source, the Qur'an presents a practical plan for tilāwa until the Day of Judgment. Since the first Prophetic mission is to read and recite the Qur'an and rehearse its $\bar{a} y \bar{a} t$ so his umma can continue the mission, the Qur'an presents a practical plan for how to recite, understand, and allow the $\bar{a} y \bar{a} t$ to enter their readers' hearts and change their lives. This recitation is the best way to strengthen one's faith, steadfastness, and mindfulness of God - all of which will lead to spiritual growth and tazkiya.

1. Gradual learning: The Qur'an explains why it was revealed in the form of responses to the Qurayshi pagans: "The disbelievers also ask, 'Why was the Qur'an not sent down to him all at once?' We sent it in this way to strengthen your heart [O Prophet]. We gave it to you in gradual revelation" (25:32) and "It is a recitation that We have revealed in parts so that you can recite it to humanity in stages. We have sent it down little by little" (17:106).

Tartīl denotes "regularity, articulation, and being well-ordered." Sūrat alMuzammil explains this process: "and [during that time] recite the Qur'an calmly and distinctly, with your mind attuned to its meaning (73:4). Here it implies articulate, eloquent, and contemplating the recitation of the Qur'an's verses and reflecting upon their meanings and impacts upon one's life. This practical step illustrates gradual change. Flexible pacing is key in this regard, for it lets people feel that they are not being rushed to learn new concepts or being held back if they learn them too quickly. This was exemplified by the Companions, both men and women, who were in the habit of learning and practicing the verses at the same time.

For example, Abu Abd al-Rahman al-Aslami reported: "The Companions of the Prophet (pbuh) would learn ten verses from the Messenger of God and would not take another ten verses until they had learned their meaning and ruling. They said, 'We would learn knowledge and action together.",18 They also taught what they had learned by helping others memorize the Qur'an and, most importantly, through their practical example, which reflected directly what they had learned from it. ${ }^{19}$ Transformational teaching changes people's lives so that they can, in turn, inspire positive changes in those who follow them. Change requires the murabbi to have

\footnotetext{
18 Source: Musnad Ahmad, 22971.

${ }^{19}$ Abu Abdullah al-Qurtubi, Jāmi ' li-Ahkām al-Qur'ān: Tafsīr al-Qurțubī (Dar al-Fikr, n.d), 1:52. Many authentic narrations urge Muslims to learn the Qur'an. The Prophet said: "The best of you is he who learns the Qur'an and teaches it to others." Șahīh al-Bukhārī, 5027, Book 66, Hadith 49. USC-MSA web (English).
} 
patience and hikma (wisdom), for successful and lasting change can only be attained via these two qualities.

2. Gradual teaching: A second important reason was to allow its teachings to slowly enter the hearts and lives of its first recipients. The Qur'an uses "sent down," in its various forms, well over 200 times. The second grammatical verb form - nazzalna - which reflects this gradual descent, is used in many verses, among them $2: 23$ and $97 ; 3: 3 ; 4: 47 ; 15: 9 ; 16: 89$; 17:106; and 76:23. The use of this verb form is significant because it captures the historical reality of the Qur'an's twenty-three-year descent into the earthly realm. Therefore, its content is intertwined with the realities of those early communities who witnessed its revelation. In other words, it spoke to historical and personal events within those communities that believed in it as well as those that rejected it.

One distinctive feature of the Qur'an is its direct response to what was going on among these people. For example, Sūrat al-Nūr is without question one of those süras that captured and responded directly to events on the ground. In relation to this fact, one must understand the munāsabāt al-nuz $\bar{u} l$ (the occasions of the revelation) $)^{20}$ in light of al-wahda albinā'iyya li-l-Qur'ān as a methodology. But how should we understand this genre of literature, which describes the events or questions that elicit the revelation of certain verses? What methods should we use to acquire a correct understanding of their meanings? What do the questions asked by the first generation of Muslims, both men and women, show us, in our current context, about the questions we should be asking of the Qur'an?

3. Listening to the Qur'an: Another powerful and emphasized method in the context of tilāwa is: "When the Qur'an is read, listen to it with attention and remain silent so that you may receive mercy" (7:204) and "Remember your Lord deep in your very soul, in all humility and awe, without raising your voice, morning and evening. Do not be one of the heedless" (7:205). The Quraysh realized the power of listening to the Qur'an, and history records instances among their elite members who would sneak away to listen to the Prophet or the Companions recite it at night. In other words, they highly discouraged people from listening to its verses out of fear that it may soften their hearts and make them vulnerable to receiving the message.

\footnotetext{
${ }^{20}$ Al-Suyuti n.d., 28. For further readings about the coherence of the Qur'an, see Mir 1986, 29-30
} and 61-62. 
The Qur'an describes this reaction in detail: "Those who reject faith say: 'Listen not to this Qur'an, but talk at random while it is being recited, [so] that you may gain the upper hand" (41:26). In another situation, the Qur'an illustrates their reaction visually: "And when Our verses are recited to them as clear evidences, you recognize the disgust on the faces of those who deny the truth. It is almost as if they are going to attack those who recite to them Our verses. Say, "Then shall I tell you of [what is] worse than that? It is the Fire that God has promised to those who are bent on denying the truth. What an evil destination" (22:72).

The Qur'an takes us to yet another scene to tell us how the Prophet (pbuh) reacted to their actions: "We know that you, [O Prophet], are saddened by what they say. And indeed, they do not call you untruthful, but it is God's messages that the wrongdoers deny" (6:33). God proceeds to tell His Prophet (pbuh) about what the Qurayshi leaders discussed when they secretly listened to him reciting it: "We are fully aware of what they wish to hear when they listen to you, what they say when they converse in private, and when the wrongdoers say, "You are only following a man who is bewitched" (17:47).

In Madina, the Prophet (pbuh) taught the Companions how listen to the recitation on different occasions, sometimes during such large and wellattended gatherings as the Friday congregational prayers. Imam Ahmad recorded that Umm Hisham bint Haritha said, "For around two years, or a year and a part of another year, our oven and the oven of the Prophet was one and the same. I memorized Sūra ( $Q \bar{a} f$. By the Glorious Qur'an.) from the tongue of the Messenger of Allah, who used to recite it every Friday while standing on the minbar delivering the Friday sermon to the people.'",21

This practice apparently continued after the Prophet (pbuh) died, for Rabi'a narrated: Umar ibn al-Khattab recited Sürat an-Nahl on a Friday on the pulpit. When he reached the verse of sujüd al-tilāwa (prostration of the recitation), he left the pulpit and prostrated. The people also prostrated. The next Friday, he recited the same süra and, upon reaching the same

${ }^{21}$ Ibn Kathir, Tafsīr Sūrah Qāf; Tafsìr Ibn Kathīr, Part 26 of 30: Al-Ahqāf 001. Muslim collected this hadith. Abu Dawud also recorded that al-Harith bin al-Nu'man's daughter said, "I only memorized Sürah Qāf from the mouth of the Messenger of Allah, who used to recite it in every Friday khutbah. Our oven and the oven of the Messenger was one and the same."' Muslim and alNasa'i collected this hadith. Sahịh Muslim, 872. 
verse, said, "O people, when we recite the verses of (prostration of the recitation) during the sermon, whoever prostrates does the right thing. However, it is no sin for the one who does not prostrate." And he did not prostrate (that day). ${ }^{22}$ This indicates that the people were continuously engaged with the Qur'an.

4. Contemplating the Qur'an on a personal level: The Qur'an encourages its readers to contemplate and engage in a dialogue with its $\bar{a} y \bar{a} t$, for "(This is) a Book that We have sent down unto you [O Muhammad], full of blessings, for people to ponder over its messages, and so that those with understanding may receive admonition" (38:29). The readers are encouraged to reflect, ask questions, seek clarity, and draw inspiration from it in ways that complicate, nuance, and ultimately enrich their views and refine their practices: "Do they not ponder on the Qur'an? If it had been from anyone other than God, they would have found much inconsistency in it" (4:82). The Qur'an continually encourages people to contemplate in order to broaden their horizons: "Have they not pondered over the word of God? Has something come to them that did not come to their forefathers?" (23:68). And, finally, it warns people that if they do not contemplate the Qur'an, their hearts will become locked and hardened. In that case, they reach the stage of häjir (abandonment): "The Messengers will say, 'O my Sustainer! Truly, my people had abandoned this Qur'an'" $(25: 30)$.

Approaching the Qur'an during the time of its revelation was based on dialogue, an on-ongoing interaction between the people and the revelation. People raised their questions and issues, and then the revelation answered them. The Qur'an states at least fifteen times: "They ask you about...." Most of the questions mentioned in the divine text are related to social, economic, and legal issues. The impact of a holistic tilāwa of the Qur'an transformed ordinary men and women into social justice activists and social scientists, as happened to Khawla bint Tha'laba, whom it taught to identify wrong customs and work hard to change them. The Qur'an represents her as a role model for humanity (59:1-4), indicating thereby that it invites its readers to ask questions and seek its guidance in order to inaugurate a positive change in their situation.

5. English-speakers rely heavily on translations to interpret the Qur'an's original message. Given that translations vary in form, content, and quality

${ }^{22}$ Șahịh al-Bukhārī, Vol. 2, Book 19 (Prostration during recitation of the Qur'an), 183. 
and depend upon human interpreters, it is critical to understand which translations to use in which instances. Sometimes only a combination of multiple translations can provide a clear picture of the true meaning and intent behind what is being said in Arabic. This exercise requires a reading buddy with whom one can discuss the meaning and understand the Qur'anic message. Therefore, reading different translations is important, and the more accurate the translated versions read, the closer they come to the original text. This method also trains readers to double- and triplecheck a translation that does not coincide with the chapter's overall theme and harmony.

The Prophetic mission of tilāwa reveals a comprehensive model for eradicating illiteracy organically. Tilāwa, the Qur'anic-Prophetic holistic approach, presents education as the art of cultivating the intellectual, moral, emotional, physical, psychological, and spiritual dimensions of human development. Illiteracy is a harmful phenomenon that not only affects the individuals themselves in their daily lives and their future, but also has a significant impact upon their society. Unfortunately, illiteracy among Muslims today is still high and remains a dangerous challenge in most Muslim nations. Due to many complex factors related to the political, cultural, economic, social, and demographic conditions, this negative reality threatens the stability of both people as well as socio-political institutions. How should a murabbi implement tilāwa to promote literacy and broadcast knowledge as the Prophet (pbuh) did?

This holistic approach helps train people to learn about themselves, their relationships, their responsibilities, and reverence for all of life. The role of the murabbi in observing the development of students or followers is very critical. Here, we can observe the Qur'an and the Prophet's (pbuh) teaching strategies: listening to each person and helping them express their feelings in order to help them grow in purity (tazkiya). The Qur'an also provides methods to assess tilāwa's impact upon people. This process helps develop one's self-awareness skills, which are key to helping people understand their place in this world. Not only is self-awareness the state of consciously being present in terms of one's thoughts, feelings, and emotions, but it also allows people to bring clarity to their internal state so they can better manage their external environment. Based on the first community's experience, the constant reading of the Qur'an while contemplating its verses was a collective movement that included all believers. This effective method gradually brought about their intimate relationship with the Qur'an, which then led to a holistic transformation in their lives.

True believers are those whose hearts tremble with awe at the mention of God, and whose faith grows stronger as they listen to His revelations, and 
who place their trust in their Sustainer - those who are constant in prayer and spend on others out of what We provide for them as sustenance. Such are the true believers. They have a high standing in their Sustainer's sight, and forgiveness of sins and a most excellent sustenance. (8:2-4)

This Qur'anic-Prophetic model of engaging with the Qur'an encourages people to see the beauty of what is around them and learn to hold life in awe. This is not limited to the first generation, but is for all generations until the Day of Judgment: "Those whom We have given this Book read/recite/follow it as it ought to be $\mathrm{read} / \mathrm{recited} /$ followed. It is they who [truly] believe in it, whereas all who choose to deny its truth - it is they, they who are the losers" (2:121).

\section{Conclusion}

The Qur'an promotes cooperation and a complementary relationship among people to fulfill their mission on Earth. By applying the term murabbi in all its derivative forms in the Qur'an, this article presents this Qur'anic-Prophetic model as one that encompasses teaching, mentoring, advising, and guiding. This article concludes that a close analysis of the Prophet's (pbuh) role as a murabbī holds practical applications for evolving Muslim communities today by providing a transformative model of leadership through the holistic guidance of the Qur'an, the ultimate source of tarbiyya.

More specifically, we should leverage the method of al-wahda albinā'iyya li-l-Qur'ān to actualize and present the term murabbī by using the Prophet's (pbuh) mission as a roadmap for spawning a social revolution driven by accountability, mercy, and compassion. The Prophet (pbuh) embodied and cultivated compassion and mercy through his words and his actions (21:107). The Sunna represents the ethics, morals, and behaviors outlined in the Shari'a. The Qur'anic notion of murabbi reflects a holistic relationship among the Qur'an, the Sunna, and the hadith (the prophetic tradition). As murabbiss, the onus is on us to transform and purify ourselves, which will, in turn, transform our society. As the Qur'an states; "God will not change what is in a people until they change what is in themselves" (13:11). 


\section{References}

Abdel Haleem, M. A. S. Trans. The Qur'an: A New Translation. New York: Oxford University Press, 2004.

al-Alwani, Taha Jabir. Al-Waḥda al-binā'iya lil-Qur'ān. Cairo: Matba'at alShuruq al-Dawliya, 2006.

- Reviving the Balance: The Authority of the Qur'an and the Status of the Sunnah. Translated by Nancy Roberts. London and Washington: The International Institute of Islamic Thought, 2017.

Ali, Abdullah Yusuf, trans. The Meaning of the Holy Qur'an, 11th ed. Beltsville, MD: amana publications. 2016.

Alwani, Zainab. "Al-wahda al-binā'iyya li-l-Qur'ān: A Methodology for Understanding the Qur'an in the Modern Day," Journal of Islamic Faith and Practice 1, no. 1 (March 2018): 7-27. https://journals.iupui.edu/index.php/JIFP.

Asad, Muhammad, trans. The Message of the Qur'ān. Mecca: Muslim World League, 1964.

al-Biqa'i, Burhan al-Din ibn Umar. Nażm al-Durar fì Tanāsub al-Āyāt wa alSuwar. Edited by 'Abd al-Raziq al-Mahdi. Beirut: Dar al-Kutub al'Ilmiyya, 1995.

Brown, Jonathan A. C. Muhammad: A Very Short Introduction. Oxford University Press, 2011.

- Misquoting Muhammad: The Challenge and Choices of Interpreting the Prophet's Legacy. Oneworld Publications. 2014.

al-Bukhari, Muhammad ibn Isma'il. The Translation of the Meanings of Sahīh alBukhārī. 9 vols., 4th ed. Translated by Muhammad Muhsin Khan. Chicago: 1979.

al-Fayadh, Mohammed Jaber. Al-Amthāl fī al-Qur'ān al-Karìm / The Proverbs of the Glorious Qur'an. 2nd ed. Herndon, USA: International Institute of Islamic Thought, 1995. 
The Journal of Islamic Faith and Practice // Volume 2, Issue 2

Haykal, M. H. The Life of Muhammad. Translated by Isma'il Raji A. al-Faruqi. Indianapolis: American Trust Publications, 1976 and 2005.

al-Isfahani, al-Raghib. Al-Mufradāt fï Gharīb al-Qur'ān, ed. Muhammad Seyd Kaylani. Beirut: Dar al-Ma'rifa.

Mir, Mustansir, Coherence in the Qur'ān: A Study of Islāhì's Concept of Nazm in Tadabbur-i-Qur'ān. Indianapolis: 1986.

—. "The Sura as a Unity: A Twentieth-Century Development in Qur'an Exegesis." In Approaches to the Qur'an. Edited by G. R. Hawting and Abdul-Kader A. Shareef. London: Routledge, 1993.

Muslim ibn Hajjaj al-Qushayrī. Șaḥịh Muslim: Being Traditions of the Sayings and Doings of the Prophet Muhammad as Narrated by His Companions and Compiled under the Title Al-Jāmi'-uṣ-Sahīh by Imām Muslim. Translated by 'Abdul Hamid Siddiqi. Lahore, 1971-1975.

al-Nawawi, Yahya ibn Sharaf. Gardens of the Righteous: Riyadh as-Salihin of Imam Nawawi. Translated by Muhammad Zafrullah Khan. London, 1980.

Ramadan, Tariq. Footsteps of the Prophet: Lessons from the Life of Muhammad. London: Oxford University Press, 2007. 